\title{
STUDIES OF THE APPALACHIAN KARST: 1770 - PRESENT
}

\author{
Ernst H. Kastning \\ Consulting Geologist and Historian, P.O. Box 1404, Radford, Virginia 24143, ernst@skyhopper.net
}

\begin{abstract}
The Appalachian region, extending from New England to Alabama, includes one of the most extensive regions of karst in the United States. It is a complex geologic terrain and has been studied for nearly 250 years. The history of karst study in the region is organized into eight frames of time: (1) Early American Notes and Records, (2) Age of Curiosity, (3) Exploration and Early Tourism, (4) Birth of Modern U.S. Speleology, (5) Landmark Speleogenetic Studies, (6) Organized Caving and Science, (7) Speleological Inflation, and (8) Applied and Environmental Science. Karst science has progressed from merely descriptive accounts to detailed scientific study. The beginnings of cave exploration, cave tourism, and development of organized speleology is rooted in this region. Environmental issues regarding karst in the Appalachians have intensified in recent decades, making the understanding of karst processes and historic perspective much more important.
\end{abstract}

\section{Introduction}

The fold belt of the Appalachian tectonic system includes one of the most extensive and contiguous regions of karst in the United States. It extends for over $2000 \mathrm{~km}$ $(1240 \mathrm{mi})$, from the New England states in the northeast to Alabama in the southeast (Davies, 1970, Herak and Stringfield, 1972, Kastning, 1986, Weary and Doctor, 2014, Palmer and Palmer, 2009). Fourteen states have substantial areas of karst lying within this nearly linear zone: Vermont, Massachusetts, Connecticut, New York, New Jersey, Pennsylvania, Maryland, West Virginia, Virginia, Kentucky, North Carolina, Tennessee, Georgia, and Alabama.

This is the third Appalachian Karst Symposium (AKS) and is being held at the U.S. Fish and Wildlife Service National Conservation Training Center, Shepherdstown, West Virginia, 2-6 April 2018. The first symposium was convened at Radford University, Radford, Virginia on 23-26 March 1991. It convened in honor of the 50th anniversary of the National Speleological Society (NSS). All 31 papers and 2 abstracts were published by the NSS in a proceedings volume (Kastning and Kastning, 1991).
The second Appalachian Karst Symposium was held at the East Tennessee State University and General Shale Brick Natural History Museum and Visitor Center, Gray, Tennessee, on 7-10 May 2008. More than 30 papers were presented at the meeting. No proceedings volume was published, however, six papers were selected and subsequently published in the Journal of Cave and Karst Studies in the August and December 2009 issues (v. 71 nos. 2 and 3 ).

\section{Significance of Appalachian Karst}

One measure of the speleological importance of this region is the abundance of caves. Caves can be an important measure of karst (Curl, 1966, 1999). Approximately $30 \%$ of 1130 caves of the United States longer than one mile $(1.61 \mathrm{~km})$ are located within the Appalachian karst (as currently listed by Gulden 2018). This percentage is the same for sub-intervals of length (e.g., caves longer than 2, 3, 4, 5, $10 \mathrm{~km}$ ).

The Appalachian region has a wide diversity of karst, providing a natural 'laboratory' for karst science (Palmer, 2007; White and White, 2009). The lithology and stratigraphy of soluble rocks (namely limestone, dolostone, and marble) varies considerably. Bedrock structure ranges from relatively flat-lying beds in the Appalachian Plateau sub-area, west of the mountain belt, to steeply dipping rocks characteristic of the intensely folded and faulted rocks of the fold belt itself. As expected, these factors have influenced the hydrogeology. Groundwater paths in the karst are complex, reflecting local geologic and topographic settings. Overall, the entire region lies within a humid-temperate zone and thus serves as a climatological type-locality.

Studies of the caves and karst of the Appalachian region began in the late 18th century. For some time, until the mid-19th century, speleological investigations in the United States were largely confined to this region, with few exceptions. Hence, the study of karst in the U.S. had its beginnings in the Appalachian region. Later, over the next 150 years, studies of karst spread westward to the rest of the country. 
The history of karst science in the Appalachians can be divided into several periods to facilitate this overview. These are as follows: (1) Early American Notes and Records, (2) Age of Curiosity, (3) Exploration and Early Tourism, (4) Birth of Modern U.S. Speleology, (5) Landmark Speleogenetic Studies, (6) Organized Caving and Science, (7) Speleological Inflation, and (8) Applied and Environmental Science. The following is a concise summary of karst studies in the Appalachians. In the interest of space, the vast number of potential references in the literature are not included here; however, many can be found in those papers cited.

\section{Early American Notes and Records}

It is difficult to ascertain just when speleological study first began in the U.S. However, the earliest records are merely descriptions of caves and other karst features discovered during exploration, travels, and settling of new territories during Colonial times and after the founding of the U.S. Many early writings on American speleology have been listed by Speece (1981), including several that describe caves in the Appalachian region.

The first well-known accounts of karst in the region refer to features in the central part of the Shenandoah Valley of Virginia. The renowned Natural Bridge near Lexington, a substantial karst landform, was first described by the Marquis de Francois Jean Chastellux (1787), and a detailed map and views of the bridge were included in his book (reproduced in Kastning 2014). Thomas Jefferson, second president of the U.S., also described the bridge in his classic book (1787), Notes on the State of Virginia. Furthermore, editions of this book also included a map of Madison's Cave in Cave Hill, near Grottoes, Virginia (Jefferson, 1787; Kastning III, 1995; Kastning III et al., 1995). This is widely regarded as the first American cave map. It is interesting to note that Madison Cave has a large signature of George Washington on its wall. Washington was a land surveyor at Natural Bridge during his early years. Jefferson was an ardent scientist. One of his contributions was a study of bones of a giant ground sloth discovered in Haynes Cave, Monroe County, Virginia (Grady, 1997).

\section{Age of Curiosity}

Many caves and other karst features were described by writers during the early 19th century, in books, newspapers, and other early periodicals (see Speece 1981 and Kastning 1981 for citations). In general, these are generally accounts of caves encountered during travels. A notable example is a description of Balls Cave in Schoharie County, New York that was published and republished in numerous newspapers in the early 1830 s and in the Monthly American Journal of Geology and Natural Science in 1832 and the American Journal of Science in 1835 (Kastning, 1971; 1979). Hence, Balls Cave was one of earliest caves to appear in the Appalachian scientific literature.

\section{Exploration and Early Tourism}

Interest in caves surged during the mid-19th century as more caves were discovered and people frequented caves that were operated for visitation. The first three notable show caves in the U.S. were Mammoth Cave in central Kentucky, Weirs Cave in Grottoes, Virginia (within Cave Hill, and presently known as Grand Caverns), and Howe's Cave (known today as Howe Caverns) in Schoharie County, New York. Fountain and Madison caves, also in Cave Hill at Grottoes, Virginia, were shown to the public as well. Later, Luray Caverns in another Cave Hill in Page County, Virginia, was discovered in 1878 and joined the ranks of the most popular and documented show caves of the time. These caves received world-wide coverage in the literature and visitation grew in response. Concurrently, some scientists of the period were drawn to visit the caves and began to decipher the mechanisms of their origin. The history of Grand Caverns is discussed in Kastning III et al. (1995), that of Luray Caverns by Gurnee (1978) and that of Howe's Cave by Kastning (1978, 1979), Cudmore (2002), and Engel (2014). These sources provide numerous references to the early works.

In addition to these most celebrated caves, numerous accounts of smaller, yet important caves in the Appalachian region were also published during the mid-19th century. Many of these writings are listed in Northrup et al. (1998), a major resource to the literature of American speleology.

\section{Birth of Modern U.S. Speleology}

Perhaps the most important era in the origin of Appalachian karst science occurred during the late 19th and early 20th centuries. European studies of karst were well underway at this time, perhaps owing to a longer history in the discovery and exploration of caves. In the U.S. it is widely acknowledged that Horace Carter Hovey may rightfully be called the 'Father of American 
Speleology.' His popular book, Celebrated American Caverns (1882), stands out as a landmark publication in American speleology. It discusses the origin of caves and much of the book is dedicated to Mammoth Cave in Kentucky. However, two Appalachian caves that were considered in detail are Howe's Cave in New York and Luray Caverns in Virginia. There is some information on other caves, including Balls Cave (New York) and caves of the Shenandoah Valley (Virginia), especially those in Cave Hill at Grottoes.

During this same period other descriptive studies of caves in various regions of the country were being published. Several came from the northeastern part of the Appalachian region, including works by Edwin Swift Balch, Lewis Caleb Beck, Herdman Fitzgerald Cleland, John Hawley Cook, Amos Eaton, James Eights, Ebenezer Emmons, Amadeus William Grabau, Edward Hitchcock, George Henry Hudson, W.H. Knoepfel, William Williams Mather, George Brubank Shattuck, and Charles Upham Shepard. Some of these authors were noted geologists of the day. A synopsis of these pioneer speleologists and their work is provided in Kastning (1981).

Significantly, this period marks the beginnings of systematic cave surveys and inventories. Among the pioneering scientists listed above, two stand out in this regard. Grabau (1906), a noted geologist of this era, described several caves in the Helderberg Plateau, just west of Albany, New York. Cook (1907), working in the same region for the New York State Museum (which includes the state geological survey), compiled what is arguably one of the most thorough descriptive and illustrated compilations of caves up to that time.

The early 1930s saw the publication of several cave inventories by other state geological surveys. Stone (1932) produced the first statewide survey of caves in Pennsylvania, and McGill (1933) authored a remarkable volume describing and illustrating the show caves of Virginia. Decades later these were later upgraded and published by the National Speleological Society and the two state geological surveys.

Alabama also began to inventory its caves (Varnedoe, 2008). Henry McCalley described about two dozen caves in Special Reports of the Geological Survey of Alabama in 1896. In 1930 the survey published Special
Report No. 16, titled, Ground Waters of North Alabama. A chapter by Walter B. Jones described 22 caves in detail. This is now recognized as the beginning of the present Alabama Cave Survey that has since published additional compilations.

\section{Landmark Speleogenetic Studies}

True karst science in the U.S. began and flourished with landmark papers on speleogenesis appearing in the geologic literature from 1930 to the early 1960s. Oddly, much of this work seems to have been done with little regard or knowledge of major contemporary karst research in Europe, particularly in the classic karst of central Europe and in France.

The American discourse on the origin of caves formed by dissolution began with considerable controversy as several competitive theories were advanced to explain the general origin of caves. Some of the most notable of the American theories advanced during this period were by J. Harlen Bretz, William E. Davies, William Morris Davis, James H. Gardner, Arthur M. Piper, Roger Rhoades and M.N. Sinacori, A.C. Swinnerton, and Herbert P. Woodward. In most cases, caves of the Appalachian region were included as examples or as case studies. Again, the Appalachian region was for some time the center of speleological activity, prior to extended exploration to other parts of the nation.

Most of these pioneering papers have been reprinted in Sweeting (1981). Reviews and discussions of the classic papers are found in White (1959), Halliday (1960), Davies (1966), Watson and White (1985), Feinberg et al. (2016), and many of the modern texts on speleogenesis and karst processes (cited in the following section).

\section{Organized Caving and Science}

The study of karst and the science of speleology made great strides during the last three decades of the 20th century. Three factors were in play. First, a plethora of regional and statewide cave surveys and inventories were compiled and published during the remainder of the 20th century. In addition to the forerunners in New York and Alabama (above), many surveys of Appalachian caves were formally published by state geological surveys as issues of their numbered series of reports. These include New Jersey, Pennsylvania, Maryland, West Virginia, Virginia, and Tennessee. Moreover, in other states, including Vermont, Massachusetts, Connecticut, 
New York, Kentucky, North Carolina, Georgia, and Alabama, similar publications were produced by internal organizations (grottoes, regions, surveys, etc.) of the National Speleological Society (NSS, see below). Some of these groups continue to extend the previous work of the state geological surveys. The publications produced from these efforts are far too numerous to cite here; however, the reader can easily find them through bibliographical searches.

The published surveys and inventories, along with associated archived files have resulted in huge data bases. These have a high value to continued cave exploration. More importantly, these sources of information have had an immeasurable impact on the research of karst throughout the Appalachian region.

The second factor in the facilitation and expansion of karst science is the advent of organized caving. The National Speleological Society was founded in 1941 through the merger of two established caving groups, one in New England and the other in the national capital region. Beyond question, the NSS, through unifying the entire speleological community, has accelerated karst research in the U.S. All interests in caves, ranging from recreation to professional scientific study were now under a single umbrella. Information began to be disseminated among all parties. The NSS resources, including publications, internal organizations, meetings, gatherings, and other events at local, regional, and national levels benefitted all interest groups. Some of these resources and activities have been general in nature, but many became specialized, addressing specific needs, including a focus on science (such as studies of karst). Without the NSS and the caving community, karst science would not be at the level it is today. The history of the NSS and its effect on karst science have been well documented (Moore et al., 1966; Davies, 1966; Damon, 1991; 2016).

The third factor in fostering the phenomenal growth in karst science during this period has been the founding of other complimentary associations and sub-groups. Also, events and meetings dedicated to karst processes and issues have emerged significantly over the years.

In the Appalachian region, Pennsylvania, West Virginia, Virginia, Kentucky, Tennessee, Georgia, and Alabama have well-organized speleological surveys and data repositories. Caves in those states continue to be documented in various publications including the MidAppalachian Region Bulletin, West Virginia Caver, Virginia Cellars, Western Kentucky Speleological Survey, Georgia Speleological Survey Bulletin. Caves in Vermont, Massachusetts, New York, and New Jersey are regularly reported in the regional Northeastern Caver.

Compilations of caves in specific regions are published often. These include guidebooks for the annual convention of the NSS and for semi-annual regional meetings and outings, including those of the Northeastern Regional Organization, Mid-Appalachian Region, Virginia Region, and Southeastern Regional Association.

Almost all grottoes (NSS chapters) regularly publish newsletters. Many include new discoveries, descriptions, and maps. These are archived in the NSS library in Huntsville, Alabama. Taken together, such newsletters and local guidebooks, published in low quantities, are a large data base for speleological research.

Another major development in Appalachian karst science has been the founding of several organizations that focus on karst research and sponsor meetings emphasizing scientific advances. The Karst Waters Institute, headquartered in West Virginia, regularly holds symposia on karst and publishes its proceedings. The National Cave and Karst Research Institute, in Carlsbad, New Mexico, sponsors meetings that often include presentations on Appalachian karst (including the present AKS). Since 1984, the Multidisciplinary Conference on Sinkholes and the Engineering and Environmental Impacts of Karst (commonly known as the 'Sinkhole Conference') meets approximately biannually. There have been 15 meetings to date including the one being held concurrently with the AKS in 2018. Many papers related to the Appalachian region have been presented and published in its proceedings. Typically, the annual and regional meetings of the Geological Society of America include papers, in some cases, entire sessions on karst. Each year the annual NSS Convention has a geology session and occasionally a session on local karst studies.

During the last few decades numerous significant and landmark papers on karst have appeared in established geoscience journals. Moreover, several major reference volumes on caves and karst have been published during this period (e.g., Klimchouk et al., 2000; Gunn, 2004; 
Ford and Williams, 2007; Palmer, 2007; White and Culver, 2007, 2011). Martin and White (2008) identify the present state of karst research and the frontiers for further study.

Taken together these contributions have advanced karst science appreciably since the 1970s. Karst science in the Appalachian region has both contributed to and benefitted from these activities.

\section{Speleological Inflation}

A quick review of the speleological literature over the last few decades reveals an astounding trend: exploration of karst regions worldwide has been increasing at a surprising rate. New caves are being discovered in amazing numbers and records for the longest and deepest continually change. Some of the most aweinspiring caves are coming to light and many existing caves have been significantly extended in length and depth. It had been thought that significant new finds in the Appalachian region would be on the decrease. On the contrary, new significant discoveries have also been the norm in most of the states in the region. Newly developed techniques of exploration, searching new areas for caves, and excavation for new entrances have all contributed to the discoveries.

Concomitant with accelerated exploration and documentation of caves and karst features has been a significant increase of professional contributions in the established geologic literature, including books, journals, proceedings volumes, and the like (White and White, 1998; Florea et al., 2005).

A number of sub-regions within the Appalachian karst area have seen a considerable explosion in exploration, mapping, and geologic study in recent years. Significant examples include (1) the marble zones of the Green Mountains of Vermont (various issues of the Northeastern Caver and guidebooks of the Northeastern Regional Organization of the NSS), (2) the Burnsville Cove Area in Bath County, Virginia (White, 2015), and (3) the Greenbrier Valley of West Virginia (White, 2018).

\section{Applied and Environmental Science}

A modern thrust of karst science is the application of principles and processes to environmental safety and protection. This has been a major thrust of the biennial Sinkhole Conferences (1984-present). Papers on engineering and environmental problems regarding karst abound in the technical literature. This is because (1) the sensitivity of karst to human impacts is becoming much better understood, (2) industrial and economic development is increasingly encroaching on areas of karst, (3) sensitive areas must be identified prior to the design and implementation phases, (4) construction plans are more often required to consider hazards during planning, and (5) regulating agencies and governing bodies are under pressure to solve potential or occurring problems in a timely, efficient, and cost-effective manner.

MajorenvironmentalissuesinthekarstoftheAppalachians are varied, largely governed by the complexity of karst systems in intensely deformed bedrock. Among the most important environmental considerations are (1) availability of adequate groundwater supplies, (2) chemical quality of groundwater, (3) sinkhole collapse and other ground instability, (4) protection of significant caves and karst features, and (5) preservation of sensitive subterranean biota.

Of all the major karst regions in the U.S., the Appalachian region has one of the highest population densities. Accordingly, environmental impacts will continue to be high and are likely to increase.

\section{Conclusions}

The Appalachian region includes one of the most significant karst areas in the United States. The historic development of karst science in the country is rooted here. From the late 1700s until the present, countless studies have addressed karst in the complex geologic setting of the region. This is supported by the wealth of published literature on the subject. Karst is an environmentally sensitive terrain. Not only is the historical context interesting, but as the region undergoes further economic development, it becomes increasingly necessary to understand the nature of the karst landscape, both above and below the surface, and the vast amount of information gleaned over the years.

\section{References}

Chastellux FJ. 1787. Travels in North America, in the Years 1780,1781, and 1782. London: GGJ and J Robinson.

Cook JH. 1907. Limestone caverns of eastern New York. In Clarke JM, editor, Third Report of the Director of the Science Division, 1906. Albany, (NY) New York State Museum: p. 32-51. 
Cudmore D. 2002. The Remarkable Howe Caverns Story. New York (NY): The Overlook Press.

Curl RL. 1966. Caves as a measure of karst. The Journal of Geology, 74 (5): 798-830.

Curl RL. 1999. Entranceless and fractal caves revisited. In Palmer AN, Palmer MV, Sasowsky ID (editors). Karst Modeling. Proceedings: Karst Waters Institute Special Publication 5. p. 183-185.

Damon PH Sr, editor. 1991. Caving in America: The Story of the National Speleological Society, 19411991. Huntsville (AL): National Speleological Society.

Damon PH Sr. 2016. Diamond Jubilee of the National Speleological Society. Huntsville (AL): National Speleological Society.

Davies WE. 1966. The Earth Sciences and Speleology. National Speleological Society Bulletin, 28 (1), 1-14.

Davies WE. 1970. Karstlands, In United States Geological Survey. National Atlas of the United States of America: sheet 77.

Engel T. 2014. To Rival Mammoth Cave: Howe's Cave Before It was Howe Caverns. Troy (NY): Troy Book Makers.

Feinberg JM, Yongli G, Alexander EC Jr. (editors). 2016. Caves and Karst Across Time. Geological Society of America Special Paper 516. Boulder (CO): Geological Society of America.

Florea LJ, Fratesi B, Chavez T. 2005. The reflection of karst in the online mirror: A survey within scientific databases, 1960-2005, Journal of Cave and Karst Studies, 69 (1), 229-236.

Ford DC, Williams PD. 2007. Karst Hydrogeology and Geomorphology. Chichester (UK): John Wiley and Sons.

Grabau AW. 1906. Guide to the geology and paleontology of the Schoharie Valley in eastern New York: New York State Museum Bulletin 92.

Grady FVH. 1997. The search for the cave from which Thomas Jefferson described the bones of the Megalonyx (abstract). National Speleological Society Bulletin, 59 (1): 57.

Gulden RE. 2018. USA Longest Caves. [Internet, updated 2018 January 6]; Available from: http:// www.caverbob.com/usalong.htm.

Gunn J, editor. 2004, Encyclopedia of Caves and Karst Science. New York (NY): Fitzroy Dearborn.

Gurnee RH. 1978. Discovery of Luray Caverns, Virginia: Gloster (NJ): R.H. Gurnee, Inc.

Halliday WR. 1960. Changing concepts of speleogenesis. National Speleological Society Bulletin, 22 (1) 23-29.

Herak M, Stringfield VT (editors). 1972. Karst: Important Karst Regions of the Northern
Hemisphere: New York (NY): Elsevier Publishing Company.

Hovey HC. 1882. Celebrated American Caverns, Especially Mammoth, Wyandot, and Luray. Cincinnati $(\mathrm{OH})$ : Robert Clark \& Co.

Jefferson T. 1787. Notes on the State of Virginia. London: John Stockdale.

Kastning EH. 1971. Ball's Cave, New York: One hundred forty years of exploration (abstract). National Speleological Society Bulletin, 33 (4): 152.

Kastning EH. 1978. Early accounts of Howe's Cave, Schoharie County, New York (abstract). National Speleological Society Bulletin, 40 (3): 92.

Kastning EH. 1979. Scientific, popular, romantic, and enterprising interests in Ball's and Howe's Caves, Schoharie County, New York, 1831-1900 (abstract). National Speleological Society Bulletin, 41 (4): 124.

Kastning EH. 1981. Pioneers of North American cave and karst science prior to 1930. In Beck BF (editor). Proceedings of the Eighth International Congress of Speleology, Bowling Green, Kentucky, July 18-24, 1981: Huntsville (AL): National Speleological Society. v 1. p. 247-249.

Kastning EH. 1986. Cave regions of the United States of America. In Middleton J, Waltham A (editors). The Underground Atlas: A Gazetteer of the World's Cave Regions. London (GB): Robert Hale. p. 203-220.

Kastning EH. 2014. Natural Bridge (Images of America series). Charleston (SC): Acadia Publishing.

Kastning EH III. 1995. Evolution of a karstic groundwater system, Cave Hill, Augusta County, Virginia: A multi-disciplinary study. In Beck BF (editor). Proceedings of the Fifth Multidisciplinary Conference on Sinkholes and the Engineering and Environmental Impacts of Karst. Brookfield (MA): AA Balkema. p. 141-148.

Kastning EH III, Hubbard DA Jr., Kastning EH, and Kastning KM. 1995. Origin of Caves and Karst in the Shenandoah Valley, Rockingham and Augusta Counties, Virginia: Guidebook for a Geologic Fieldtrip, National Speleological Society Annual Convention, Blacksburg, Virginia, 16 July 1995: Blacksburg (VA): Virginia Region of the National Speleological Society, Blacksburg, Virginia.

Kastning EH, Kastning KM (editors). 1991. Appalachian Karst: Proceedings of the Appalachian Karst Symposium, Radford, Virginia, March 23-26, 1991: Huntsville (AL) National Speleological Society. 
Klimchouk AB, Ford DC, Palmer AN, Dreybrodt W, (editors). 2000. Speleogenesis: Evolution of Karst Aquifers. Huntsville (AL): National Speleological Society.

Martin JB, White WB (editors). 2008. Frontiers of karst research: Leesburg (VA), Karst Waters Institute Special Publication 13.

McGill WM. 1933. Caverns of Virginia: Virginia Geological Survey Bulletin 35.

Moore GW, Zotter H, Stephenson WS, Hill WS, Staniland JL. 1966. History of the National Speleological Society. National Speleological Society Bulletin, 28 (1) 38-54.

Northrup DE, Mobley ED, Ingham KL III, and Mixon WM (editors). 1998. A Guide to Speleological Literature of the English Language 1794-1996. Dayton $(\mathrm{OH})$ : Cave Books.

Palmer AN. 2007. Cave Geology. Dayton (OH): Cave Books (Cave Research Foundation).

Palmer AN, Palmer MV. 2009. Caves and Karst of the USA: Huntsville (AL): National Speleological Society.

Speece JH. 1981. Early American Speleological Writings. Journal of Spelean History, 15 (3-4), 30-31.

Stone RW. 1932. Caves of Pennsylvania: Pennsylvania Bureau of Topographic and Geologic Survey Bulletin G-3.

Sweeting MM. 1981. Karst Geomorphology: Benchmark Papers in Geology 59: Stroudsburg (PA): Hutchinson-Ross Publishing.

Varnedoe W. 2008. History of the Alabama Cave Survey. [Internet]; Available from: https://www. alabamacavesurvey.org/history/.

Watson RA, White WB. 1985. The history of American theories of cave origin. In Drake ET, Jordan (editors). A History of North American Geology: Geological Society of American Centennial Special Volume 1. Boulder (CO): 109-123.

Weary DJ, Doctor DH. 2014. Karst in the United States: A digital map compilation and database: U.S. Geological Survey Open-File Report 2014-1156.

White WB. 1959. Speleogenesis. Netherworld News (Pittsburgh Grotto, National Speleological Society) (6) p. 273-289; (7) p. 6-26 [reprinted in Dunn JR and McGrady AD (editors). 1961 Speleo Digest - 1959: Pittsburgh (PA) National Speleological Society, p.2.1-2.34].

White WB (editor). 2015. The Caves of Burnsville Cove, Virginia: Fifty Years of Exploration and Science (Cave and Karst Systems of the World): Cham (Switzerland): Springer International Publishing.
White WB (editor). 2018. Caves and Karst of the Greenbrier Valley in West Virginia, (Cave and Karst Systems of the World): Cham (Switzerland): Springer International Publishing.

White WB, Culver DC (editors). 2007. Benchmark Papers in Karst Science: Leesburg (VA), Karst Waters Institute Special Publication 11.

White WB, Culver DC (editors). 2011. Encyclopedia of Caves. Amsterdam (NL): Academic Press.

White WB, White EL. 1998, Geology. In Northrup DE, Mobley ED, Ingham KL III, and Mixon WM (editors). 1998. A Guide to Speleological Literature of the English Language 1794-1996. Dayton (OH): Cave Books. 40-41.

White WB, White EL. 2009. The Appalachian karst: An overview. In Palmer AN and Palmer MV (editors). Caves and Karst in the USA. Huntsville (AL): National Speleological Society. p. 17-23. 
